PART ONE

Introduction 



\section{Legal Revolutions, Cosmopolitan Legal Elites, and Interconnected Histories}

The global rise of financial capitalism and neoliberal economics over the past thirty to forty years has helped produce a "legal revolution" (Berman 1983) in much of the world. Tangible results of this process include the proliferation of large corporate law firms - a US invention-in the major capitals of the world and, more recently, a trend toward legal education reform geared toward those corporate law firms and US approaches to legal education. The current legal revolution, like the earlier one in the United States, is associated with a modernist commitment to meritocracy, which can be deployed against entrenched legal elites-even oligarchies-held together by family or quasi-familial capital. The strong impact of this revolution is apparent in the major countries of Asia, including the subjects of this study-China, Hong Kong, India, Japan, and South Korea.

Our book is about this revolution and the very different ways it is playing out in those countries. But it is also about how such revolutions both attack legal hierarchies and are central to their reproduction. Richard Abel's well-known work on the legal profession emphasized professional control of markets and "the production of producers" (e.g., Abel and Lewis 1989-90) as keys to the success of the profession. In contrast, we argue that control of the production (and reproduction) of producers is applied mainly to protect those at the top of the legal hierarchies. In other words, the key strategy is not so much to restrict internal and external competition through monopoly and limited entry into the profession; rather, it is to enforce an internal hierarchy that reserves access to the top positions to a cosmopolitan elite blessed, most typically, with inherited legal capital and degrees from highly selective schools. Such elites include descendants of the French "noblesse de robe," notable "jurists" in Brazil, high court advocates and judges in India, and, in places like China, Japan, and South Korea, families with sufficient resources that their children will excel on national examinations and rise to the most respected positions. 
Those who occupy positions at the top are typically presented as having risen through meritocratic processes, when actually they have depended heavily on family, social, and economic capital, which includes access to exclusive universities and law schools. The mix of meritocratic and social capital varies from place to place and over time, but the dynamics of elite reproduction are general.

Even where the ideology of meritocracy seems dominant, as in the United States, partnerships in elite corporate law firms are open mainly to graduates from a relatively small number of law schools - that is, to those who have been schooled since birth to compete for such positions (Markovits 2015; Dinovitzer and Garth 2020). This reproduction of the "one percent" requires, as Markovits has noted, "massive, sustained, planned, and practiced investment, from birth or even in the womb" - "equivalent, economically, to a traditional inheritance of between 5 and 10 million dollars per child" (Markovitz 2015: 9). The most elite positions reproduce the advantages of social class in other ways as well. Even if someone from outside a society's privileged families "wins the economic lottery against all odds, there is a social glass ceiling. The positions of cultural, economic and political leadership - the trappings of the upper class - are much less open to them than to those who from birth and privileged education accumulate the less obvious forms of [social and cultural] capital” (Jodhka, Rehbein, and Souza 2018: 85).

This process goes back to the creation of the legal profession in medieval Italy around the University of Bologna. The top rewards of law practice have always gone primarily to a handful of individuals with strong family connections, access to substantial resources to support long years of study away from home, and expertise in cosmopolitan legal knowledge-beginning with the Roman Corpus Juris rediscovered in Italy in the eleventh century. An enduring feature of the legal profession is the survival of the inheritors of this role and of the habitus (Bourdieu 2012) that has sustained it over the centuries. Yet this system is neither linear nor unidirectional. Indeed, it is unstable and full of contradictions and detours, in part because those at the top erect barriers to preserve their places and those of their children. Challengers promoting meritocracy or a stronger emphasis on scholarly capital confront complacent legal establishments at the top of the national hierarchy. Bourdieu's sociological insights about the tensions between and complementarity of family and meritocratic capital help explain how these challenges play out (2012; 2015).

The dynamics of these challenges and the changes they generate can be understood through the concept of "legal revolution" developed by Berman (1983). Berman focused on major revolutions such as the Gregorian and Protestant revolutions, but his approach can be applied to smaller ones as well. Legal revolutions typically are characterized by the presence of relative newcomers challenging complacent legal elites who are too close to power and disinvested in legal scholarship. The newcomers combine their meritocratic and scholarly achievements to attack the legal establishment; at times, their legal theories gain salience as these 
"rebels" forge links with emerging political groups that are also rising against the status quo. The scholarly investment and orientation of political groups may also relate to shifts in imperial power that provide opportunities to challenge local legal and political power. Domestic legal shifts in the nineteenth century, for example, took place in relation to a shift in imperial policies away from economic exploitation toward a more moral and missionary approach offering a larger role for the legitimacy provided by law and lawyers. Changes in imperial centers provided local opportunities to build on law. The legal challengers ultimately refurbished and revitalized the traditional hierarchies by reaching the top of the profession and connecting with the new political elite. But as Bourdieu suggested (2012), the upstarts may themselves become complacent, conservative, and too eager to elevate family capital over scholarly capital.

Examples of the complexity of these processes abound. In the 1970s, law and development missionaries in many countries used the prestige of US legal education to challenge traditional legal oligarchies that had long resisted scholarship, meritocracy, and reforms in legal education-oligarchies such as the prominent Indian grand advocates who opposed Nehru's social reforms, and Brazilian jurists (professors, politicians, and public intellectuals with prominent legal names). The initial "failure" of reforms gave birth to a later generation who used their expertise and foreign connections to recreate the challenge by importing from the global North not only corporate law firms but also new schools to serve them. But here, as elsewhere, there were further twists and turns. The aspirational Harvard of India, the National Law School of Bangalore, founded in 1986, was a legacy of the idealistic law and development movement and of internal politics challenging the complacency of the elite bar. But it changed quickly, from a school committed to training public interest advocates to serve NGOs to the first of many National Law Schools focused on producing corporate lawyers. The US-oriented teaching produced lawyers who easily slotted into the new corporate law firms that had established themselves following India's economic liberalization. Yet many of these same graduates are now themselves challenging the traditional bench and bar.

Benton and Ford (2016) describe how Britain in the nineteenth century legalized colonial administration as well as interaction with trading partners, thus connecting the power of local elites to cosmopolitan legal expertise and imperial governance. The same process of co-optation into law and imperial power was evident even in countries that under pressure from Western empires emulated the practices of the Western colonial powers. The long and interconnected history of these practices is evident to this day, for example, in the leading law faculties in Beijing, which are distinguished by their cosmopolitanism-in particular, their expertise in Western legal theories. This is striking-China, never a Western colony, has reproduced the habitus of the cosmopolitan legal elites.

The processes that Benton and Ford describe suggest that the position of these cosmopolitan legal elites investing in formal law cannot be taken for granted. Law 
always exists in relation to underlying social structures and a multitude of methods of dispute resolution. In the nineteenth century, for example, locally embedded justices of the peace in the colonies competed against the formal law controlled by British Queen's Counsel (Benton and Ford 2016). The lesson of legal pluralism is that the place of mafias, tribes, religions, political parties, and customary law may ebb and flow depending on the power and embeddedness of formal law and its lawyers relative to those who seek to challenge them in the name of other authorities. Sida Liu (2020: 699), for example, discusses the changing role of Chinese lawyers in relation not only to state bureaucrats, market brokers, and political activists but also to "barefoot lawyers" or "basic level legal workers." Those who challenge formal law and its practitioners may replace it with other legitimating ideologies.

We cannot depict all of the twists and turns of the descendants of the small group of cosmopolitan elites that built the legal profession in medieval Italy, but we want to note that our narrative does not preclude shifts in direction that affect the role of law and lawyers. Our focus here, however, is on the relationship of legal oligarchies in Asian countries to the relatively powerful legal revolution emanating initially from the United States and identified with neoliberalism and financialization.

Some of the institutional changes associated with this neoliberal legal revolution, especially the boom in corporate law in the United States, which began in the 1980s and continues, with some hiccups, into the present, are already the subject of an established scholarly literature (e.g., Galanter and Palay 1991; Gordon 2008). The story that leading legal scholars tell is mainly one of growth in the market for corporate legal services resulting from the economic changes associated with liberalization and deregulation (see Boussebaa and Faulconbridge 2019). Law firm expansion and growing wealth are seen mainly as consequences of more general economic trends that have produced a much greater demand for corporate legal services.

The same phenomenon is now evident in much of the world. Comparative studies of the legal profession emphasize the importance of corporate law firms in many countries besides the United States. In particular, the work being done at Harvard University by David Trubek, David Wilkins, and their colleagues emphasizes that there has been a boom in corporate law in places where its practitioners are a relatively new phenomenon-most notably, Brazil, China, and India among the emerging economies (Wilkins, Khanna, and Trubek 2017; Gross Cunha, Monteiro Gabbay, Garcez Ghirardi, Trubek, and Wilkins 2018). Other scholars see the same trend in Latin America (Gomez and Pérez-Perdomo 2018). Europe, we should note, developed corporate law firms earlier, although well after the United States (Dezalay 1992). Again, the expansion and economic success of corporate law firms emulating those in the United States is attributed largely to changes in the local and global economies-liberalization and globalization. These scholars also 
point to the rise in prestige and wealth of those in the corporate sector as evidence of some convergence with the US model (albeit with local variations).

These literatures tend to accept the rise of corporate law firms in the United States and abroad as natural and inevitable-as the modernizing result of growth in demand among corporations for the services of well-trained lawyers in large organizational settings (Wilkins, Trubek, and Fong 2020; Abel and Lewis 1988-89). Other characteristics-high prestige; very high salaries, especially for partners; and hiring on the basis of merit (i.e., high grades from top law schools) - are typically seen as features that go along with corporate law firms' growth and expansion.

Neither the demand for the specific services of corporate lawyers nor the prestige of this sector can be taken for granted, however. It was not inevitable that corporate law firms would succeed when exported to settings outside the United States, and of course such "success" takes a form that depends on what was already established in the importing nation's legal field (Dezalay and Garth 2002; 2010). Success in transforming a legal field, which includes carving out a credible role for corporate law firms, requires actors and processes best depicted as legal revolutions challenging the existing legal oligarchies.

The arrival of the corporate law firm disrupted relatively stable structures. There was a two-stage process that varied by local context. Corporate law firms initially were outside the mainstream and ostracized by local legal elites, who did not initially embrace the potential demand pushed by US-style globalization. Corporate law firm entrepreneurs eventually found ways to draw elites in and gain acceptance. Stage two then involved entrepreneurs seeking to reshape legal education so as to align it with corporate practice.

The entrepreneurs of the "globalization of legal education" embrace the need to "modernize" - that is, Americanize-other countries' methods. Initiatives include promoting the JD or equivalent to replace the much more prevalent undergraduate legal education; placing greater emphasis on clinics and experiential learning; recruiting full-time professors instead of relying on part-timers; and using devices such as Harvard's Socratic method rather than passive lectures in order to encourage student engagement. The entrepreneurs, many of whom did graduate studies in the United States and then went home to "reinvest" them, also promote scholarship produced to a "global standard," derived largely from US interdisciplinary approaches.

The globalization of legal education is the theme of a rapidly growing literature celebrating and promoting these entrepreneurial initiatives (e.g., Steele and Taylor 2010; Gane and Huang, 2016; Jamin and van Caenegem 2016; Harding, Hu, and de Visser 2017). Our goal, however, is not to hail an emerging organizational convergence or an agreement on "best practices." Our focus is sociological-specifically, on the contests over legal education as part of the process of making legal revolutions that provide a central place for corporate law firms at or near the top of the 
hierarchy. The US model often challenges familial and quasi-familial establishments, which find themselves battling against change.

This existing literature tends to adopt the perspective of the US-influenced side in the contested legal revolution-that of corporate law firms, legal educational reform, and meritocratic versus familial criteria for advancement. Our approach aims to place this literature in the context of the long history of cosmopolitan legal elites and legal revolutions more generally, including the neoliberal revolution in major Asian countries. For example, instead of looking for evidence of an emerging trend consistent with US interests and practices, we focus on the actors in the local battles and on the stakes they face.

We recognize that studies of lawyers and the legal profession do not usually take the form of long histories going back to the origins of the legal profession. Giovanni Arrighi, in a new preface to The Long Twentieth Century: Money, Power, and the Origins of Our Times ([1994]2010), takes an approach similar to ours and helps explain what we hope to accomplish. Arrighi noted that his work, inspired in part by Braudel, pushed him into "recasting his investigation into a much longer time frame." Our research has similarly drawn us more into "excursions into the past" to make sense of present developments. Arrighi writes that he sought to avoid the trap of "the treacherous terrain of world historical analysis" (xii) identified with Immanuel Wallerstein (e.g., 2004) by following Charles Tilly's recommendation, which was to "deal with more manageable units of analysis than entire world systems" (p. xiii) - in his case, financial systems. Through our specific focus on the role of cosmopolitan legal elites, which in recent decades have variously resisted and participated in a legal revolution involving corporate law and complementary legal education, we can perhaps make a similar and related contribution, by showing new developments in Asia as "reflections on structures and processes that had been in place since the sixteenth century" (p. xv) or earlier.

\section{ORGANIZATION OF THE BOOK}

Our book has four parts. After this introductory chapter, the next three parts address three moments central to understanding the colonial legacies in our Asian case studies. The first part also sets the stage for the later chapters with a chapter on our theoretical approach. Chapter 2 explores the idea of legal revolution, the tension and complementarity between social and familial capital and scholarly and meritocratic capital, and the centrality of colonialism and imperialism to the interconnected histories we develop in the case studies. The chapter goes "beyond Berman and Bourdieu," whose theoretical perspectives on law and social change are central to the approach we take in this book. The chapter also draws on Lauren Benton and Lisa Ford's (2016) recent work on British colonialism and law.

We begin in Chapter 3 with the founding of the medieval law faculty at Bologna, which represents the starting point of the long history studied in this book. In the 
aftermath of Bologna, we focus especially on two diverging paths: cosmopolitan elites in Britain veered toward an approach that de-emphasized scholarly capital in favor of apprenticeships and familial capital; while on the European Continent faculties of law kept up the role of scholarly capital that had characterized medieval Bologna and the study of civil and canon law. In the countries we study, the British and German models of state and law were imposed or adopted in the nineteenth century, with China and Japan adopting the German model under imperial pressure, Korea following Japan, and Hong Kong and India shaped by British colonialism. The cosmopolitan legal elites in those countries have never been simple replicas of the West; rather, the process of local embedding has rendered them as distorted mirror images of Western institutions.

The second period explores the development of the hybrid that became the basis for US "anti-imperial imperialism." The current legal revolution stems from the rise of US power in imperial competition. As the United States grew stronger and became more active in foreign policy, its models for education and corporate law became ripe for export, including by means of the well-documented "law and development movement" in the 1960 s and 70s. The new legal revolution, unlike the earlier law and development movement, is not mainly a product of affirmative legal export policies. While it builds on that history, today it is much more about import-that is, importers are taking advantage of the huge new global market in the post-Cold War period. They are drawing on the legitimacy of law and legal approaches in the United States in order to take on and challenge their local legal oligarchies in the name of modern corporate legal practice and legal education.

Chapter 4 shows how the US approach to legal education and corporate law originated in the context of meritocratic reforms at Harvard Law School under Langdell and associated famously with the case method. The reforms at Harvard and that university's growing production of Wall Street lawyers were essential to legitimating the corporate law firm - an institution that mixed social with meritocratic capital and thus was well-positioned to serve and prosper during the Gilded Age (Coquillette and Kimball 2016). The hybrid represented a revolutionary break within the United States. It transformed the structures of the field by legitimating corporate law firms at the top of the hierarchy, supplying considerably more legal talent for representing corporations, and facilitating a concomitant huge expansion of demand for the legal services of the kind that corporate law firms provided. The legitimating of the new supply was necessary for the new demand to take root, contrary to the assumptions made by demand side theorists (Abel and Lewis 1988-89). Through this process, corporate partners came to occupy the top of the US legal hierarchy, and they have not ceded that position despite a number of challenges. The law professors who emerged in the United States drew on the Continental European legacy that valued law professors highly. And even though the elite law schools were open mainly to the well-to-do, they maintained a real selection process and provided rigorous training (Coquillote and Kimball 2016). 
As Chapter 5 shows, the relative openness of the legal profession in the United States has made it possible for corporate law firms to survive and adapt to significant state transformations, including the New Deal, the welfare state, and the rise and worldwide spread of conservatism and neoliberalism. The diffusion of neoliberalism abroad, beginning especially in the 1990s, was led by economics, but it came with and gained strength from the diffusion of corporate law firms-often in tandem with investment banks. Legal entrepreneurs found a propitious climate for promoting the formation of such law firms in many different settings outside the United States.

The US hierarchy that placed corporate partners at the top was historically unique. Who sits at the top of the legal field-whether corporate lawyers or others-depends very much on the local context. Historically, for example, in Latin America the "jurist" - professor, public intellectual, litigator, politician-has been at the top. In India, the top of the profession has been the domain of leading senior barristers, termed "grand advocates" by Galanter and Robinson (2018), and of the judges of the most prominent courts, while in Japan and South Korea, the top has been exemplified by judges and prosecutors. The historical differences are profound and continue to shape the hierarchies even as they are disrupted by the institutionalization of corporate law firms outside the United States.

The third period, discussed in Part IV, presents Asian case studies of the ascendance, especially in recent decades, of US models associated with the neoliberal legal revolution. The international legitimacy of the US model provides opportunities for local scholars and legal entrepreneurs to challenge the entrenched legal oligarchies that control access to elite legal positions. But here, too, we find a local, distorted variation of the US model.

The case studies reveal continuities in the monopolistic strategies of those at the top of the local legal hierarchies produced by imperial processes. Those strategies link together domestic political power, hegemonic and imperial relationships, and social and family capital. Also, a small core of elite law schools plays a central role in both the reproduction of legal elites and the "modernist" challenges associated with legal revolutions. Each case study examines the impact of the legal revolution within a particular national legal field. Local impacts differ substantially because of complex variations in local structures of power.

We begin with India (Chapter 6), where we see much evidence of the legal revolution, such as new US-oriented law schools and a proliferation of corporate law firms, but where we also see resistance by a strongly entrenched legal oligarchy comprised of the grand advocates and high judiciary. Hong Kong (Chapter 7), another former British colony, provides a dramatic contrast: it quickly adapted to the global balance of power, including the neoliberal revolution, but also to the growing power of China in the world and in Hong Kong.

Chapter 8 contrasts South Korea and Japan. Japan's colonial relationship with Korea from 1905 until the end of the Second World War strongly marked South 
Korea's legal system and legal profession. The faculties of law and the legal profession were Japanese-led replicas of what had been established in Japan after the Meiji Revolution. The similarities make especially stark the differences in how each country has enacted and accommodated the recent legal revolution emanating from the United States. Both countries, to be sure, have absorbed much of that revolution, including the presence of a magic circle of corporate law firms and a prominent reform in legal education toward the JD as opposed to the LL.B. But South Korea, in contrast to Japan, overcame the resistance of the core of the legal establishment (in the Judicial Research and Training Institutes) through an almost classic legal revolution according to the Berman formula.

Chapter 9 on China provides a counterpoint to the other case studies. China's long-established internationalized legal elite played a major role during the Republican Period and also helped constitute both the Kuomintang and the Communist challenge to it. This group, purged during the Anti-Rightist Campaign and the Cultural Revolution, came back after the Cultural Revolution to rebuild legal education and again imprint it with international expertise and scholarship centered on highly selective and elite schools in China. Graduates today go abroad in very large numbers, especially to the United States, and they dominate the top legal positions, including in the expanding corporate and in-house law sectors. This internationalized sector of the legal profession has adapted to changes in the field of state power. The most recent shift in Chinese power has been away from the "liberalism" and "rule of law" of the 1990s more toward a Chinese version of "rule by law." The domestic power of the internationalized group has grown as the role of law increases in the state and the economy.

The particulars of the diffusion of corporate law firms and related legal education reforms depend on evolving contests between familial and scholarly capital, as well as between lineage and meritocracy. The case studies show that in these Asian countries, the confrontation between the US-style corporate law firms and law as historically practiced (or not) can be quite dramatic, with China notable because it almost eradicated the legal profession during the Anti-Rightist Campaign and the Cultural Revolution. The other countries also illustrate what legal entrepreneurs encounter when promoting corporate law firms and related changes in legal education. Entrepreneurs, to be sure, can bypass existing legal hierarchies by ignoring them, as the Big Four accounting firms appear to be doing (Wilkins and Ferrer 2018). But the resistance that slows or stops the entrepreneurs (and that held up the Big Four in the past) mobilizes from inside the core of the legal fields. This entrepreneurship/resistance process is well-illustrated in our case studies. Despite the very different backgrounds and colonial histories, in every case we see a strong effort by groups allied with corporate law firms to reform and globalize education, including through new law schools and the US-copied JD degree. The conclusion in Part IV examines some of the themes emerging from the case studies and revisits the theoretical perspective. 
This book builds on our previous books, especially Asian Legal Revivals: Lawyers in the Shadow of Empire (2010) but also the Hong Kong chapter of Dealing in Virtue: International Commercial Arbitration and the Construction of a Transnational Legal Order (1996). The research for those books involved more than fifty interviews in each country studied, including Hong Kong, South Korea, and India. We have expanded our work here to include China and Japan. For China, we were fortunate to collaborate with Zhizhou (Leo) Wang. For Japan, which we study in conjunction with South Korea, we did not conduct interviews in Japan but were able to draw on leading authorities, especially at a conference in 2017. In 2017, we conducted twelve interviews in China (one by Wang), fifteen new interviews in Hong Kong, twenty-three in India, and thirteen in South Korea. Our method, as in previous works, has been to combine historical accounts, scholarship on law and the legal profession, and even newspaper and other Web sources to extend our knowledge. Interviewees included legal scholars and academic leaders, corporate and other lawyers, NGO lawyers, and social scientists. The interviews focused on career trajectories, including investments in politics and the state, links to foreign contacts and expertise, and strategies that interviewees individually and collectively use to build professional credibility.

The book also builds on our previous work theoretically. Our earlier work examined especially the divide between US and European approaches to law and governance, with the US approaches ascending (Dealing in Virtue 1996; The Internationalization of Palace Wars: Lawyers, Economists, and the Contest to Transform Latin American States [2002]), and we expanded that approach to examine the role of empire and imperial competition in Asian Legal Revivals (2010). We believe that our focus here on the genesis of the legal profession allows us to deepen the theoretical framework to explore not only the differences and similarities in interconnected histories but also the relationship between law and social change involving cosmopolitan elites, stemming initially from medieval Bologna, and legal revolutions seeking to shake them up.

Finally, we wish to clarify some terminology. We use terms such as lawyers, pure law, elites, neoliberalism, and the state to simplify the narrative, but we recognize they are terms that hide the fluidity and complexity of what is deemed to be represented by those names. That is why Bourdieu's concept of the fieldespecially the legal field and the field of state power-is so useful. It can be clumsy, however, to always use that term in the text. With respect to elite, it is not meant to depict some fixed group. The divide between the few and the rest is an evolving one, and any reification of the categories of elite versus non-elite is misleading. The Bourdieusian framework we employ is concerned with the evolving structure of legal fields that produce particular hierarchical relationships. The habitus and 
institutions embedded in the field are more important than categories of elite and non-elite. The key point is that the impacts of the legal revolutions we explore in this book, including the neoliberal revolution, are shaped by those occupying the centers of professional power and influence in the field, who may resist and/or seek to turn them to their advantage. 